\title{
CONCEPTUAL FRAMEWORK FOR THE STUDY OF MORAL DISTRESS IN NURSES
}

\author{
Flávia Regina Souza Ramos ${ }^{1}$, Edison Luis Devos Barlem², Maria José Menezes Brito ${ }^{3}$,Mara Ambrosina Vargas ${ }^{4}$, \\ Dulcineia Ghizoni Schneider ${ }^{5}$, Laura Cavalcanti de Farias Brehmer
}

${ }^{1}$ Ph.D. in Health and Nursing Philosophy. Professor, Departamento de Enfermagem, Pós-Graduação em Enfermagem (PEN), Universidade Federal de Santa Catarina (UFSC). Florianópolis, Santa Catarina, Brazil. E-mail: flavia.ramos@ufsc.br

2 Ph.D. in Nursing. Professor, Curso de Graduação e Pós-Graduação de Enfermagem, Universidade Federal do Rio Grande. Rio Grande, Rio Grande do Sul, Brazil. E-mail: ebarlem@gmail.com

${ }^{3}$ Ph.D. in Administration. Professor, Pós-Graduação de Enfermagem, Universidade Federal de Minas Gerais. Belo Horizonte, Minas Gerais, Brazil. E-mail: brito@enf.ufmg.br

${ }^{4}$ Ph.D. in Nursing. Professor, Departamento de Enfermagem and PEN/UFSC. Florianópolis, Santa Catarina, Brazil. E-mail: ambrosina. mara@ufsc.br

${ }^{5}$ Ph.D. in Health and Nursing Philosophy. Professor, Departamento de Enfermagem, UFSC. Florianópolis, Santa Catarina, Brasil. E-mail: dulcineiags@gmail.com

${ }^{6}$ Ph.D. in Nursing. Professor, Departamento de Enfermagem, UFSC. Florianópolis, Santa Catarina, Brazil. E-mail: laura.brehmer@ufsc.br

\begin{abstract}
The objective of this reflective study was to propose conceptual elements for the analysis of moral distress as a process that articulates various concepts of moral experience. The moral distress is explored as a phenomenon manifested in different scenarios and dimensions of labor - care, management and education. Although a relative consensus exists on the concept and comparable empirical results in several countries, there are limited studies that explore theoretical gaps, critical points and possibilities to expand the analytical potential. In the search for consistent and updated theoretical supports for the changing needs of the field, the state of the art was surveyedn and a conceptual framework was designed to address moral distress as a process that articulates various concepts or moments of moral experience, such as uncertainty, moral sensitivity and moral deliberation. The proposed matrix articulates the development process of moral competencies or the construction of the ethical subject, present in pedagogical and philosophical discourses of interest to the profession.

DESCRIPTORS: Nursing ethics. Moral. Stress, psychological. Moral damage.
\end{abstract}

\section{MARCO CONCEITUAL PARA O ESTUDO DO DISTRESSE MORAL EM ENFERMEIROS}

RESUMO: Estudo reflexivo que objetivou propor elementos conceituais para a análise do distresse moral, como processo que articula diversos conceitos da experiência moral. O distresse moral é explorado como fenômeno manifesto em diversos cenários e dimensões do trabalho - cuidado, gestão e educação. Apesar de um conceito relativamente consensual e resultados empíricos comparáveis em vários países, há limitação de estudos que explorem lacunas teóricas, pontos críticos e possibilidades de ampliação do potencial análitico. Na busca por sustentações teóricas consistentes e atualizadas às novas necessidades do campo, o estado da arte foi retomado e um marco conceitual foi delineado para a abordagem do distresse moral como processo que articula variados conceitos ou momentos da experiência moral, como o de incerteza, sensibilidade moral e deliberação moral. A matriz proposta articula o processo de desenvolvimento de competências morais ou de construção do sujeito ético, presentes em discursos pedagógicos e filosóficos que interessam à profissão.

DESCRITORES: Ética em enfermagem. Moral. Estresse psicológico. Dano moral.

\section{MARCO CONCEPTUAL PARA EL ESTUDIO DE ANGUSTIA MORAL EN ENFERMEROS}

RESUMEN: Estudio reflexivo orientado a proponer elementos conceptuales para la análisis de la angustia moral como un proceso que articula diversos conceptos de la experiencia moral. La angustia moral como fenómeno que se manifiesta es explotada en varios escenarios y dimensiones laborales - cuidado, de gestión y de educación. A pesar de un concepto relativamente consensual y resultados empíricos comparables en varios países, existen pocos estudios que exploran las lagunas teóricas, puntos críticos y las posibilidades de ampliar el potencial analítico. En la búsqueda de apoyos teóricos consistentes y actualizados a las necesidades cambiantes del campo, el estado de la técnica se ha tomado y un marco conceptual fue diseñado para hacer frente a la angustia moral como un proceso que articula diversos conceptos o momentos de la experiencia moral, como la incertidumbre, la sensibilidad deliberación moral y moral. La matriz propuesta se articula el proceso de desarrollo de la competencia moral o construcción del sujeto ético, presente en los discursos pedagógicos y filosóficos de interés para la profesión

DESCRIPTORES: Ética en enfermería. Morale. Estrés psicológico. Daño moral. 


\section{INTRODUCTION}

Concerns with the ethical or moral dimension of labor is continuously reinvigorated by new issues of multidisciplinary interest. Specifically in the contexts of health work, at least two main complementary and interdependente axes of ethical problematization are observed, which are: 1 ) the problems, dilemas and possibilities of failure/error/ damage surrounding moral decisions involved in health practices, that is, the axis about the wellbeing of people who are receiving care and, at bottom, the consequences of professional, institutional and political priorizations and deliberations about the life and health of individuals, groups and communities; 2) the experience of the professional facing these problems who, having different decision conditions and technical and moral competencies, are also victims of the consequences of this deliberation process, that is, the axis on the impacts in how the professionals can atribute meanings to the relations and results of their activities, build career perspectives and achieve satisfactory subjective relations with their own work.

The theme anguish, suffering or moral distress, discussed as one and the same phenomenon here, refers directly to the second problematization axis on the working subject, but is produced at the interface with and also influences the first axes, in which of the consequences for the care offered and for the subject receiving the care. In English, studies use the terms moral distress and moral suffering, the first of which has become better known, although many authors do not make any distinction. In Brazil, moral distress has been translated as sofrimento moral. In this study, although terms like anguish, affliction or moral suffering are accepted, to acknowledge the origin of the term and the possibility of a literal translation into Portuguese, the term distresse was chosen.

The first concept of moral distress discussed in nursing was proposed in the United States by the philosopher Jameton, as the distress (anguish, affliction, suffering) that is manifested when the professional knows what is the right thing to do, but institutional constraints prevent him/her from taking the morally correct course of action. ${ }^{1}$ Acknowledging the bias in this concept, in the next decade, its author further developed it, distinguishing between initial and reactive distress. In the first, the nurses experience feelings of frustration, anger, anxiety when confronted with institutional obstacles and interpersonal value conflicts. Reactive distress, then, is felt when the professionals are unable to cope with the initial anguish. ${ }^{2}$ Based on this second type of anguish (reactive), the definition of moral residue or persistent distress ${ }^{3}$ was developed as the cumulative effect of moral distress. The wound for having acted against one's own values remains, breaking with moral integrity and leaving marks in one's personality and value system. ${ }^{4}$ Moral integrity refers to the undissociable relation between professional and personal integrity, as it also relates to a pattern that is morally accepted by society. When moral integrity is impaired, moral suffering may happen, and even the abandonment of the profession. ${ }^{4-5}$

Based on these pioneer studies, moral suffering was disseminated as the experience in which the nurse is aware of the morally correct action but, due to institutional obstacles or conflicts with other individuals, is unable to act according to his/ her knowledge or moral premises and may even perform morally inappropriate actions. ${ }^{2,6}$

The literature demonstrates that, despite the existence of a relatively consensual conceptual framework and comparable empirical results in different contexts, a great limitation exists in terms of studies that go deeper into the moral distress phenomenon, exploring the range of scenarios and dimensions of nursing work - care, management and education. In addition, theoretical models or conceptual frameworks need strengthening and expansion to support studies for the current research stage.

Based on the motivation to support future theoretical models of moral distress, the objective of this reflection was outlined, which is: to propose conceptual elements for the analysis of moral distress as a process that articulates other concepts or moments of the moral experience. Therefore, the current stage of development of the concept (or construct, in line with the approach intended here) was recovered in order to raise critical issues and possibilities to enhance and advance the knowledge on this research object, which represents an important problem in nursing work.

This proposal emerged from the first author's reflections, as the responsible researcher for an ongoing multicenter research about the process of nurses' moral anguish/suffering in different contexts of health work in Brazil. These reflections were deepened and supported by contributions of research groups from the three universities involved in the research, including the co-authors of this manuscript. 


\section{Advances, gaps and new issues in moral distress}

To summarize the state of the art on moral distress/suffering/anguish, some elements need to be retrieved about which different international authors have more or less agreed. The key element to trigger moral distress is the feeling of impotence, the inability to perform the action perceived as ethically appropriate. ${ }^{2}$ It can be caused by internal or external constraints on the nurses' behavior. The internal causes were related to insecurity, lack of confidence in conflict situations, pressures and inequality of power. ${ }^{2,7}$ The external causes were related to specific situations, involving clinical decisions, the process of death and dying, inappropriateness of material and human resources, lack of professional qualification, among others. ${ }^{8}$

Although empirical research results led to the recognition of the causes of moral distress, not all nurses submitted to the same circumstances will necessarily experience it or can develop it in other situations. ${ }^{3,8}$ If the members of the health team perceived the moral values and obligations differently, the moral suffering will be an individual experience instead of a defined situation. ${ }^{3}$

The characteristics of nursing work are related to the complex and diversified demands for ethical positioning, as well as to a more favorable position to perceive the patients' potentials and beliefs and intervene on their behalf, that is, greater potential for advocacy, so that needs are attended to and rights are guaranteed. ${ }^{9}$ Moral distress can be related to the professional's lack of advocacy, in a vicious circle that leads to lesser contact with the patients, enhancing their discomfort and the nurses' anguish. It ends up threatening the nurses' integrity, retention and the abandonment of work and the profession. ${ }^{8}$

Reference is made to moral distress related to the care management role, when nurses face problems related to priority setting, resource limitations and organizational policies, ${ }^{10}$ or lack of voice in view of unfair institutional practices. ${ }^{11}$ In general, their situations can be similar to those of clinical nurses, but there are differences in roles and responsibilities, which can change the perception and manifestation of the phenomenon.

The consequences and manifestations of moral suffering are not always easy to apprehend, ranging from more clearly identifiable expressions, such as feelings of anger and frustration, to expressions that are difficult to verbalize or understand, such as self-depreciation, silent de- valuation, isolation, all of which represent threats on moral integrity. ${ }^{3}$

Arguments in the literature on nursing ethics reveal different terms of normative meanings of moral distress (outlined in 20 articles published between 1993 and 2013), including: 1) moral judgment, 2) personal and professional identity and integrity, 3) moral competencies and 4) moral responsibility. ${ }^{12}$

In view of the diversity and technological complexity of their work, nursing worked to discover expressions, causes and intensities of this process, besides possible implications for professionals and for the quality of nursing practices. For this type of concern, tools have been developed, particularly instruments and scales, in order to quantify the moral suffering of nurses in specific contexts.

In 1995, Corley's pioneer proposal, the Moral Distress Scale, to measure the intensity and frequency of moral suffering, was applied to intensive care nurses and, later, to medical and surgical clinical nurses, analyzing variables of age, race and length of experience. ${ }^{13}$ Other studies were also applied to work in intensive care units, in psychiatric nursing, in care delivery to critical and severe patients, in surgery rooms or in oncology and pediatric services, among others. ${ }^{10,14-18}$

In Brazil, Corley's tool was validated and later adapted in 2012 and $2014 .{ }^{19}$ Among other studies, in the same research group, the theme was discussed in relation to the Burnout syndrome, to the autonomy and to power and resistance practices. This set of studies and reflections promoted a sensitive presentation of this object to Brazilian nursing. . $^{2-24}$

Using the validated and adapted Moral Distress Scale, ${ }^{19}$ five constructs were identified: lack of competency in the work team; disrespect for the patient's autonomy, insufficient work conditions; denial of the role of nursing in advocacy for terminal patients and denial of the role of nursing in patient advocacy. The applied version included daily work situations of nurses, nursing technicians and auxiliary nurses in hospitals, some of which differ from the situations described in international studies, which highlighted the importance of thw work environments and organization forms. It was demonstrated that the perceived causes of moral suffering are intensified in nurses, in nursing workers active at institutions that are more open to dialogue, which organize team meetings, with shorter work journeys and a higher e maior relação no número de profissionais por pacientes.

In summary, the investigation of moral distress has been expanding since the 1980's in the 
global context and since 2000 in Brazil, especially in the hospital context. The challenge is to explore the expressions and elements related to nurses' moral suffering in the Brazilian context, in the different work contexts and complexity levels of health care, with new conceptual proposals for support.

In very recent studies, a new and complex set of challenges has been appointed, no longer focused on the demand to get to know the specific forms in which moral distress manifests in different contexts, but on exploring gaps and limitations in the classical concepts and their premises, to support a new phase of theoretically and methodologically more consent studies. . $^{3,6,9,25-26}$

One example is the notion of nurses as incarnated moral agents, whose experience integrates mind, brain, body and emotions. The agents are expected to express their professional ethical mandates, often restricted by the sociopolitical structures of the health context. To enhance the understanding of the relations between structure and moral agency in their mutual influences, the combination with neuroscientific knowledge is proposed. ${ }^{25}$

Another important source of criticism appoints controversial elements in the use of the moral distress concept, to the extent of questioning whether it is time for nursing to abandon a faulty construct. The arguments for this fault include the risk of tales of moral suffering serving more to confound than to clarify the ethical dimensions of nursing work, without contributing to guarantee the moral competency of people and institutions offering health care. ${ }^{26}$

Little has been studied, for example, about the psychological and ethical background of nurses' coping with ethical issues. Resting on the presumption that nurses know what is the right thing to do is questionable, especially based on three weaknesses in this idea: assuming the unmistakable correction and justification of the nurses' moral judgments, without expressing the bases for these judgments and hardly admitting that they might be mistaken or wrong; underestimating nurses' moral responsibility to act, even when confronted with difficult obstacles and environments, in an apology of their disabilities; and using a type of fallacy (petitio principii or begging the question), defending a thesis departing from the principle that it is valid, that is, that a causal relationship exists between moral distress and two related phenomena, correct moral judgments and nurses' impotence to act. ${ }^{26}$

The first weakness is the most interesting to highlight here as, to propose a conceptual frame- work, it is truly problematic to depart from this premise or not to question its insufficiency. The author alerts to reports that nurses tend to decide and justify their moral actions by calling on their own personal values and experiences, instead of using ethical and critical reasoning or pertinent theoretical bases. Hence, ethical decisions in practice are based on personal convictions, religious beliefs, education, intuition and feelings or collective desires. ${ }^{26}$

Personal or mass opinions are not sufficient for moral justification, no matter how well intentioned. In addition, there are reports that trust in one's own values increases with professional experience, leading to stricter positions and stronger reactions when confronted, such as irritation and anxiety, as if the mere length of practice produced correct judgments. The result can be the 'moral imposition' from the nurses' viewpoint, even when they defend a value or principle, such as autonomy, to the detriment of others that emerge in multicultural contexts. ${ }^{26}$

The acknowledgement of the current gaps and questions should stimulate further appropriations and critical formations to expand the professionals' knowledge and capacity to cope with the roots and implications of this complex ethical problem.

\section{Proposals for a conceptual model of moral distress}

The first premise in this proposal is an expanded perspective on moral distress as a process and, at the same time, as a singular experience, which integrates the moral or ethical experience. Ethics and morality are considered indistinctly, without the classical distinction between a regulatory and relatively imposed cultural base and another reflected and theorized base, acknowledged as philosophical thinking. What should be recognized here is the human experience of becoming the moral subject of one's actions. Thus, the ethical-moral experience can be highlighted as continuous, infinite and productive in terms of subjectivity and identity.

Without using direct references, in this premise, the influence of Foucault's thinking should be acknowledged. Preliminarily, Kant's idea of discretion and the importance of education for freedom and citizenship should be acknowledged - the subject producing morality in him/ herself. ${ }^{27}$ But it is in Foucault, who assumes the ontology of the present as his historical object, that the different modes through which human beings turn into subjects make the ethical and political problem more evident. ${ }^{28}$ 
Ethics is one of the central axes in the constitution of the subject, as it is situated in the relation with oneself, as the rational and reflected practice of freedom. This subject is produced in different subjectification modalities, never in singular places or trajects, but in devices, practices and discourse. In that perspective, ethics is the esthetics of existence, a study on itself guided by the set of arts of existence, that is, practices through which men establish rules of conduct for themselves, attempt to transform themselves and turn life into a work with style and esthetic values. Turning into a moral subject means putting oneself as the target of one's own knowledge and action. ${ }^{29}$

Based on this author, the notion of experience articulates fields of knowledge, normativeness and forms of subjectivity, so that moral distress/ anguish/suffering starts to be considered an element of this ongoing exercise on oneself, or at least it should be, as it would tighten certain positions and behaviors to mobilize change and freedom. That is the productive sense of moral suffering - to integrate the experience of the self, to participate in the construction of the ethical subject.
The process-based nature of moral distress does not mean that it cannot be studies as an episodic phenomenon, which relates causes and effects, but that this approach is insufficient to understand its productive potential, or what remains when the episode has ended, when the subject will no longer be the same.

The constitution of the subject also includes the construction of professional identities, as it is assumed that nursing keeps a relative career perspective, with intensive education, dedication and adherence to professional values and discourse; despite the current questioning of the subjective centrality of work or its capacity to give meaning to life. Professional identities are not fixed or unchangeable but process-based; like moral experience, they are crossed by institutions, knowledge and practices.

The process-based perspective of moral distress implies that, in its analysis, other concepts or elements of the ethical experience should be articulated. These elements are schematically presented in the analytic model, figure 1.

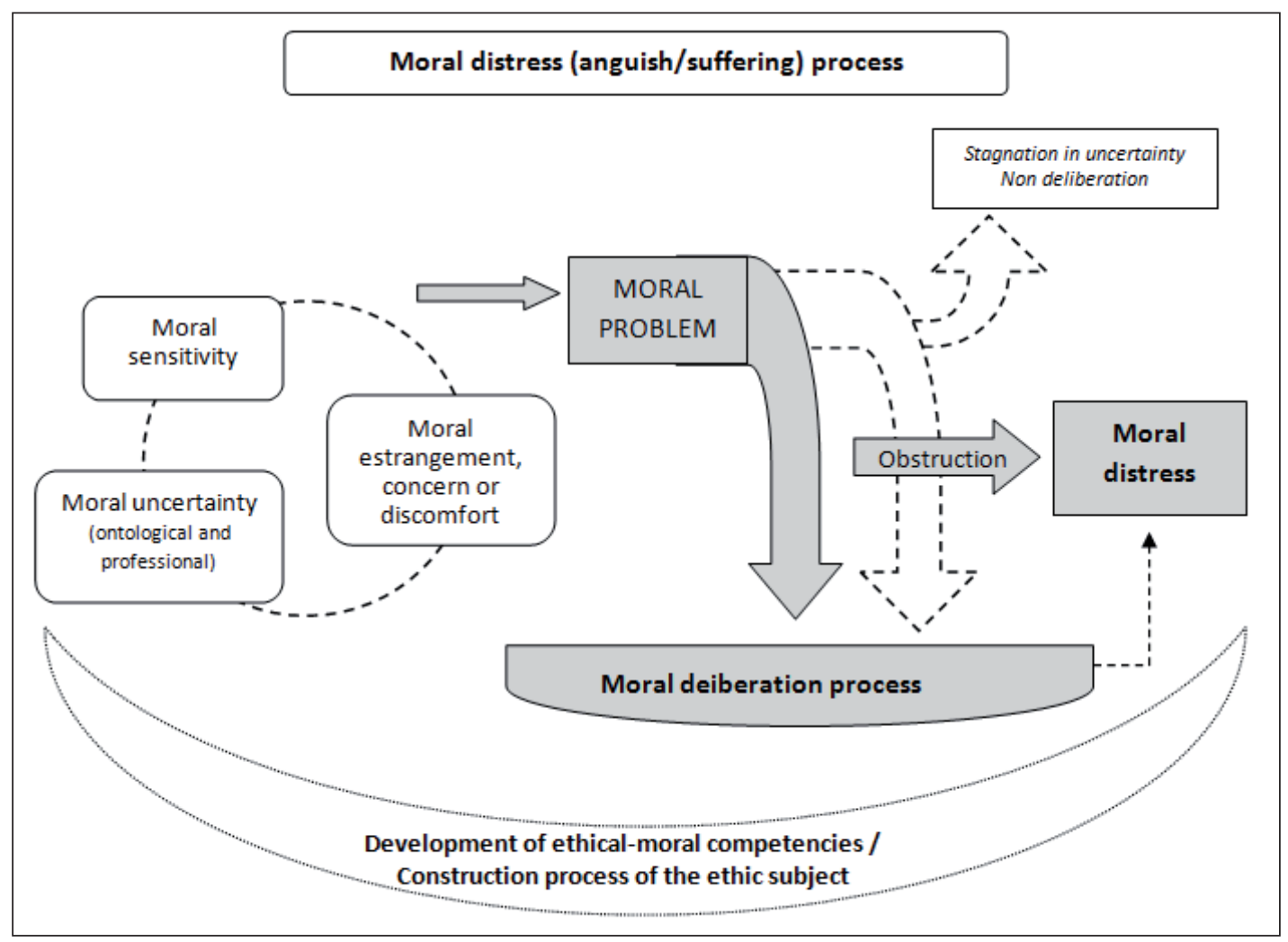

Figure 1 - Schematic matrix - Conceptual framework for the analysis of the moral distress process. Florianópolis-SC, Brazil, 2015

The notion of moral problem is the starting point or core element in the moral distress process. There is no moral decision when the subject is not confronted with a problem that requires a position. And there is no moral suffering if this decision is put in practice and produces the expected effects. 
Problem is what mobilizes moral reflection, what makes the subject question the situation and him/ herself, which demands more than trained, reliable and technically correct action. The moral problem emerges when trust is weak, when the established rules and routine actions give no response as to the choices that are to be made and, also, when these choices remit to personal and professional values, often conflicting among the agents involved.

Moral problem, as an object the subject reflects on, does not exist independently of the person who perceives it. A fact or question can be considered as a moral problem by some while not even being noticed by others. For a moral problem to be visible, moral sensitivity is needed, as a distinguished ability to perceive, a refinement, education or orchestration of perception. Hence, as the exercise of observing develops the observer and his/her observations, the sensitivity focused on moral issues is exercised, promoted, expanded by experience. This does not mean that all types of experience or the mere accumulation of experience or lifetime determine greater moral sensitivity, but the moral experience from Foucault's perspective mentioned earlier, of reflected practices on oneself. This implies the recognition not only of the other, but of what constitutes the self and the other, of the forms of acting, thinking and being, constructed inside a culture, of knowledge, standards and institutions.

Nurses have already reported on moral sensitivity as a positive attribute or skill to recognize an ethical problem or the ethical dimension of a situation, even without an apparent conflict. This includes the contextual and intuitive understanding of the patient's vulnerability, besides the ethical consequences of any decision made on his/her behalf, which is why it is a prerequisite for appropriate decision making and ethically engaged conduct. ${ }^{30}$

Ethical sensitivity was also defined as what allows professionals to acknowledge, interpret and respond appropriately to the concerns of the people receiving their professional services. A study of 200 articles and books that adopted the concept in 12 different disciplines, including Nursing, Medicine, Psychology, Bioethics, Law and Philosophy, revealed preconditions, attributes and results as dimensions of the concept. Hence, in professional practice, ethical sensitivity develops in contexts of uncertainty, suffering and vulnerability of the client through relations of receptiveness, responsiveness and courage by the professionals (preconditions of the client and the professional); with moral perception, affection and tension/weighting between questions (loyalties) as its attributes. The results of ethical sensitivity refer to the integrity of decision taking, comfort and wellbeing, self-transcendence and professional growth. ${ }^{31}$

In this model, moral or ethical sensitivity is considered a fundamental element for a moral problem to be perceived and taken as an object of inquiry and criticism. In this sense, it does not differ from the concept adopted in international studies, when it was introduced as a concept relevant to the science of care, to describe the first component of decision making in professional practice, the acknowledgement and interpretation of the ethical dimension of a care situation, or as a type of practical knowledge. ${ }^{31}$ Nevertheless, the perspective adopted here does not explore attributes or results of moral sensitivity, since it is inserted in the construct of moral suffering, in its relations with moral deliberation and the development process of moral competencies, in which these aspects are explored, but not as exckysuve dimensions of sensitivity.

It is interesting to appoint that moral sensitivity is dynamic, developing and related to uncertainty and moral discomfort. Moral uncertainty can be considered from the ontological viewpoint, as a characteristic of rationality and human life, no matter the circumstances, while professional uncertainty refers to the insufficiency of knowledge and the circumstances of professional work, which impose coping with the plurality of values, targets and interpretations of these same circumstances and acts. Uncertainty is positive and productive, as it stimulates the sensitivity and awareness of one's own limits; is resistant to conviction and comfort, which eliminate doubt and opening to other perspectives and possible responses. Therefore, moral discomfort is considered in its productivity, as an element of concern and non-accomodation to common practices and/or estrangement towards facts, attitudes or modes of acting.

Another important distinction present in the literature exists between moral dilemma, moral uncertainty and moral distress. In moral dilemma, the focus is on the indecision about a value conflict. That is, in a certain situation, there is more than one correct decision to make but, when deciding on one of the alternatives, the other is necessarily annulled. Moral uncertainty, in turn, is understood as insecurity about the morality of the action performed or difficulty to define an action as correct or not., ${ }^{2,32-33} \mathrm{In}$ moral distress, the focus changes from indecision or doubt to the impossibility or blocking of that action that is correct or desired by the subject. 
Although these authors did not intend to clearly distinguish between moral dilema and uncertainty, some ponderations on the use of these terms are considered here. Initially, it is considered that, although the trade-off approach has gained visibility, especially with the bioethical discussions, it is insufficient to address most of the moral issues in health practice. That is so because dilemma designates a choice between two unique alternatives, in this case excluding countless challenges that rather represent a problem than a dilemma, that is, they appoint different possibilities or courses of action, as broad as the bases to support the moral judgments they mobilize.

In summary, based on the above, the construct of moral distress starts to be considered with the connotations of a process, called the moral distress process. As a process, it is articulated with the development dynamics of the ethical-moral competencies in the course of existence and, therefore, in a close relation with the moral uncertainty as inherent in the human condition and in social (ontological) life and professional practice. Coping with the challenges that require ethical-moral positions is part of the subjects' social constructions, with uncertainty as a mobilizing and triggering element of these coping experiences. In this dynamic, the subjects develop moral sensitivity, or conditions to perceive the moral content of daily actions, facts and thoughts. This perception can be accompanied or nurtured by more intense feelings of estrangement, concern or moral discomfort. These feelings are not necessarily linked to negative or unpleasant effects on the subject, but are considered in their productivity, as conditions for reflection and moral deliberation, mainly granting visibility to the moral problems that could otherwise remain hidden or estranged from personal experience.

Based on the finding of moral problems, this model produces derivations for other concepts or elements, following the chain of the process. The moral problem can mobilize at least three possible trajectories (represented by the three arrows in the Figure 1): stagnation in uncertainty, when the deliberation process is not developed and ethicalmoral positioning or coping with the problem does not take place; the moral deliberation process as a whole, including moments or actions of joining significant information, outlining alternatives, reviewing criteria and reaching a solution, affirming the position and acting, assessing the decision made (according to a classical model in Nursing, from 1985); the incompleteness of moral deliberation due to bottlenecks or obstacles for the selected decision or course of action to take place and for the professional to be able to act in accordance with his moral judgment. ${ }^{34}$ The latter case corresponds best to the concept of moral distress presented in the literature, as discussed.

To study the moral distress process, the concept of moral deliberation process is added as a method of practical reasoning that is frequently applied to the field of bioethics, especially in clinical bioethics. Despite the existence of different methods proposed to guide moral analysis, all of them seek to promote the rational, systematic and objective study of the moral conflicts that emerge in the care practices or in specific committees. As a tool for the results of the decision to be more correct, these methods cannot do without training and discussion because, at least in some branches, moral deliberation itself implies the relation of different stakeholders that aim for a shared solution, based on the practice of dialogue, non-coercion, criticism and opening to change views and positions. ${ }^{35}$

A study ${ }^{35}$ that proposed a method to analyze cases of ethical infractions by nursing professionals concluded that the model that emerged from the discourse and practices expressed in this type of ethical processes presented good coherence with the methods proposed in different North American and European bioethicists, including the model disclosed by a Nursing expert. The (mnemonic) model called MORAL ${ }^{34}$ combines the nursing process with the principles of biomedical ethics to clarify ethical problems related to conflicts, producing new discernments, obligations and duties. Its components are: $\mathrm{M}$ (massage the dilemma) - Join significant information and define what is involved in the decision process; $\mathrm{O}$ (outline options) - Outline options or identify alterntaives, causes and consequences of each; R (review criteria and resolve) - Review criteria and reach a solution. Identify and analyze the moral criteria to select those that best match the case; A (affirm position and act) - including (ACT), A for anticipating objections and obstacles to the action, C for clarifying the position and planning responses to the objections and obstables, $\mathrm{T}$ for testing the choice; L (look back) - Assess the decision made.

It is possible and not contradictory to assume the similarity between the widely authorized concept of moral distress and the concept that considers moral distress as an obstacle or bottleneck for the moral deliberation process. They are similar because they share the singular experience and awareness of the ethically appropriate action, in the interve- 
nience of an impediment or obstacle, whether due to internal restriction, external restriction or conflict with other people, which produces helplessness and inability to act in accordance with one's decision.

What is evidenced that that this impossibility interrupts the course of the moral deliberation process, exactly when taking a position and acting, making the process inconclusive (did not reach its objective), sterile (did not lead anywhere) or even insulting for the professional (produced an improper, offensive and morally incorrect effect). In other words, a new notion of moral distress process is assumed, complementary to the classical concept, in which it starts to be considered as a bottleneck for the satisfactory conclusion or achievement of the goal of the moral deliberation process, which produces the consequences the previously presented authors appointed. That concept is similar or close to the literature, represented in the figure 1 by the largest dotted arrow, crossed by the obstruction arrow.

What is added in this framework is the possibility to consider that distress can also occur afterwards, after the action and the desired course were taken, but still within the moral deliberation process; specifically in the assessment phase, when the range and effectively obtained results are considered from a perspective of greater distancing and critical reflection on the moral deliberation developed. Now, thus far, the quality of the deliberation process has not been discussed, nor in most of the studies.

At the end of the process, the moral deliberation process can be assessed from the perspective of different inquiries: if the action taken coincided with the positions initially assumed; if concepts and positions were modified in the course of the process; if convictions and earlier bases were relativized; if the perspective on the problem was expanded, if rational discussion took place among different stakeholders; if a consistent moral justification was produced; if the strength of the arguments was maintained in the retrospective assessment or if other arguments gained more strength; if the capacity to make ethical judgments is promoted, among others.

These questions can lead to a negative assessment of the process or its outcomes, even when the position or course of action the professional defined earlier prevailed. This gap or risk has been reported ${ }^{26}$ when ignoring that the nurses' judgments can be mistaken, based on deep-seated convictions, interests, feelings or beliefs, or not submitted to criticism. From the angle taken here, the moral deliberation process can be compromised in its underlying foundations, dialogicity and opening, impairing its quality and purpose. In these cases, if an ethically responsible and critical assessment is made, could moral suffering result, not because the action is impeded, but because of the awareness that the judgment made is erratic?

Whether this perspective indicates a complement to the construct of moral distress or the need for a new concept demands reflection. As the notion of process is defended here, beyond the simple occurrence of moral distress, this type of relation with moral deliberation should be included - in situations of mistake, insufficiency or non-achievement of the expected results. This would correspond to the possibility to consider the positive aspect of the unexpected result for the development of moral competencies. That would be like admitting that, even guided by the final target of the most correct moral action - intrinsic in the practice of excellence, as the action is post-facto reassessed as not the best alternative to conduct the problem, which can be a source of reflection and improvement in future processes. If considered as moral distress, happened through another route or at another time in the deliberation process, what was discussed above on Foucault's ethical perspective is reconsidered - the productive sense of moral suffering, when part of the experience of the self in the construction of the ethical subject.

\section{FINAL CONSIDERATIONS}

Conclusions do not apply to this kind of study, but mere indications for future developments, which can address questions on the application and limits of the moral distress construct, the advances and gaps reported in studies in different countries and work contexts of nurses.

The main expressions of moral distress could be explored, including Brazilian researchers' effort. Nevertheless, theoretical models need to be developed that support the analysis of the object, considering its complexity and new perspectives. Support like what was presented in this study are only meaningful as a permanent exercise of criticism against the existing reference frameworks and models, to promote a new phase of research, using updated theoretical and methodological support for the new needs of the Nursing knowledge area.

The search for conceptual consistency cannot be abandoned, neither in the name of the demands to know the different and singular forms in which 
moral distress is manifested, nor in the name of the temporary nature of the proposals or the complexity of the task.

The conceptual framework outlined advanced by discussin moral distress as a process that articulates several concepts or moments of the moral experience, such as moral sensitivity and moral deliberation. In addition, it should be considered that the different concepts associated in this matrix are profoundly involved in the development of moral competencies, currently evidenced in the pedagogical and professional discourse, as continuously developing in the coruse of life and work and as requisites for good professional practice. At the same time, other possible foci should be used, such as that of a philosophical base that articulates these moral experiences with the construction process of the ethical subject.

The potential of this type of study lies in the propelling of criticism against the use of concepts and reference frameworks that help to understand the problems of professional practices and that can somehow support the ethical subject's reflection on his/her own knowledge and action.

\section{REFERENCES}

1. Jameton A. Nursing practice: the ethical issues. Prentice-Hall: Englewood Cliffs; 1984.

2. Jameton A. Dilems of moral distress: moral responsibility and nursing practice. AWHONNS Clin Issues Perinat Womens Health Nurs. 1993; 4(4):542-51.

3. Epstein EG, Delgado S. Understanding and addressing moral distress. Online J Issues Nurs [online]. 2010 [cited 2014 Fev 02]; 15(3):25-34. Available from: http://www.nursingworld.org/ MainMenuCategories/EthicsStandards/Courageand-Distress/Understanding-Moral-Distress.html

4. Hardingham LB. Integrity and moral residue: Nurses as participants in a moral community. Nurs Philos. 2004 Jul; 5(2):127-34.

5. Lunardi VL, Barlem ELD, Bulhosa MS, Santos SSC, Lunardi Filho WD, Silveira RS, et al. Sofrimento moral e a dimensão ética no trabalho da enfermagem. Rev Bras Enferm. 2009; 62(1):599-603.

6. Barlem ELD, Ramos FRS. Constructing a theoretical model of moral distress. Nurs Ethics. 2015 Aug [cited 2015 Jun 27]; 22(5):608-15. Available from: http://nej.sagepub.com/content/ early/2014/10/31/0969733014551595

7. Hamric AB, Davis WS, Childress MD. Moral distress in health care professionals. Pharos. 2006; 69(1):16-23.

8. Corley MC. Nurse moral distress: a proposed theory and research agenda. Nurs Ethics. 2002; 9(6):636-50.
9. Hanks RG. The lived experience of nursing advocacy. Nurs Ethics. 2008; 15(4):468-77.

10. Mitton C, Peacock S, Storch J, Smith N, Cornelissen E. Moral distress among health system managers: exploratory research in two British Columbia health authorities. Health Care Anal. 2011; 19(1):107-21.

11. Gaudine AP, Beaton MR. Employed to go against one's values: nurse managers' accounts of ethical conflict with their organizations. Can J Nurs Res. 2002; 34(2):17-34.

12. Mccarthy J, Gastmans C. Moral distress: A review of the argument-based nursing ethics literature. Nurs Ethics. 2015; 22(1):131-52

13. Corley MC, Minick P, Elswick RK, Jacobs M. Nurse moral distress and ethical work environment. Nurs Ethics. 2005; 12(4):381-90.

14. Cohen JS, Erikson JM. Ethical dilemmas and moral distress in oncology nursing practice. Clin J Oncol Nurs. 2006 Dec; 10(6):775-80.

15. Mekechuk J. Moral distress in the pediatric intensive care unit: the impact on pediatric nurses. Int J Health Care Qual Assur Inc Leadersh Health Serv. 2006; 19(4-5):i-vi.

16. Ohnishi K, Ohgushi Y, Nakano M, Fujii H, Tanaka $\mathrm{H}$, Kitaoka K, et al. Moral distress experienced by psychiatric nurses in Japan. Nurs Ethics. 2010; 17(6):726-40.

17. Edmonson C. Moral courage and the nurse leader. Online J Issues Nurs [online]. 2010 [cited 2014 Set 21]; 15(3):5-30. Available from: http:/ / www.nursingworld.org/MainMenuCategories / EthicsStandards / Courage-and-Distress / MoralCourage-for-Nurse-Leaders.html

18. AFT SLK. Moral distress in medical surgical nurses [thesis]. Cullowhee (US): Western Carolina University; 2011.

19. Barlem ELD, Lunardi VL, Lunardi GL, TomaschewskiBarlem JG, Almeida AS, Hirsch CD. Psycometric characteristics of the Moral Distress Scale in Brazilian nursing professionals. Texto Contexto Enferm. 2014 [cited 2015 Jun 27]; 23(3):563-72. Available from: http:// www.scielo.br/scielo.php?pid=S010407072014000300563\&script=sci_arttext

20. Barlem ELD, Lunardi VL Tomaschewski-Barlem JG, Lunardi GL, Lunardi Filho WD, Schwonke CRGB. Moral distress: challenges for an autonomous nursing professional practice. Rev Esc Enferm USP. 2013; 47(2):506-10.

21. Barlem ELD, Lunardi VL, Lunardi GL, TomaschewskiBarlem JG, Silveira RS. Moral distress in everyday nursing: hidden traces of power and resistance. Rev Latino-Am Enfermagem. 2013; 21(1):293-9.

22. Dalmolin GL, Lunardi VL, Barlem ELD, Silveira RS. Implications of moral distress on nurses and its similarities with Burnout. Texto Contexto Enferm. 2012; 21(1):200-8. 
23. Dalmolin GL, Lunardi VL, Lunardi GL, Barlem ELD, Silveira RS. Moral distress and Burnout syndrome: are there relationships between these phenomena in nursing workers?. Rev Latino-Am Enfermagem. 2014; 22(1):35-42.

24. Dalmolin GL, Lunardi VL, Lunardi GL, Silveira RS, Barlem ELD. Nurses, nursing technicians and assistants: who experiences more moral distress Rev Esc Enferm USP. 2014; 48(3):521-9.

25. Musto LC, Rodney PA, Vanderheide R. Toward interventions to address moral distress: navigating structure and agency. Nurs Ethics. 2015; 22(1):91-102.

26. Johnstone MJ, Hutchinson A. 'Moral distress' - time to abandon a flawed nursing construct? Nurs Ethics. 2015 Feb; 22(1):5-14.

27. Kant I. Sobre a pedagogia. $3^{\mathrm{a}}$ ed. Piracicaba (SP): UNIMEP; 2002.

28. Foucault M. O sujeito e o poder In: Rabinow P, Dreyfus H. Michel Foucault, uma trajetória filosófica: para além do estruturalismo e da hermenêutica. $2^{\mathrm{a}}$ ed. Rio de Janeiro (RJ): Forense Universitária; 2012. p. 231-49.

29. Foucault M. O uso das prazeres a as técnicas de si. In: Foucault M. Ética, política, sexulaidade. $2^{\mathrm{a}}$ ed. Rio de Janeiro (RJ): Forense Univesitaria; 2010. p.192-217.

30. Huang FF, Yang Q, Zhang J, Khoshnood K, Zhang JP. Chinese nurses' perceived barriers and facilitators of ethical sensitivity. Nurs Ethics [internet]. 2015 Mar 29 [cited 2015 Jun 28]. pii: 0969733015574925. Available from: http://nej.sagepub.com/content/ early/2015/03/27/0969733015574925

31. Weaver K, Morse J, Mitcham C. Ethical sensitivity in professional practice: concept analysis. J Adv Nurs. 2008 Jun; 62(5):607-18.

32. Corley MC, Elswick RK, Gorman M, Clor T. Development and evaluation of moral distress scale. J Adv Nurs. 2001 Jan; 33(2):250-6.

33. Gutierrez KM. Critical care nurses' perceptions of and responses to moral distress. Dimens Crit Care Nurs. 2005 Sep-Oct; 24(5):229-41.

34. Crisham P. Moral: how can I do what's right? Critical Care Management Edition. Nurs Manage. 1985; 16(3):42A-42N.

35. Schneider DG, Ramos FR. Moral deliberation and nursing ethics cases: Elements of a methodological proposal. Nurs Ethics. 2012; 19(1):764-76. 